\title{
THE COMMUNICATION SOCIETY AND THE MEDIA CULTURE
}

\author{
Oana-Antonia ILIE \\ "Nicolae Bălcescu" Land Forces Academy, Sibiu, Romania \\ antonia_ilie@yahoo.com
}

\begin{abstract}
Any knowledge is recorded, set in the culture and in the end, communicated. The communicative behaviors are found at the basis of humanization, of the spiritual, psychological and social development of people. To exist as a human being means to communicate, moreover communication is the major factor present in the constitution and transmission of the cultural values and of culture itself. The emergence of the new media confronts us with the challenge of abandoning the old means and of replacing the old values with those of the media culture. The communication society responds to the dream of mankind to create and live in a better world: it guarantees freedom of expression, free information, instantaneity, and all the attributes and illusions of a best possible world. On the other hand, the crisis of confidence faced by the media in the recent years is an important moment and an alarming signal for the media institutions. However, enthusiasm for the online media has increased, especially among the young people who, despite the inconveniences, access the virtual space in greater number year by year. Ultimately, regardless of the criticism surrounding the media culture, the purpose of the creators has always been to communicate the new created values, because only through communication the new forms of culture can emerge and establish themselves as culture.
\end{abstract}

\section{Keywords: comunication, media culture, communication society, confidence crisis}

\section{The universal communication}

According to the first axiom of the Palo Alto School, a communication universalis seems to be the constant of the modern society and the key to the contemporary social discourse. It is impossible not to communicate: all social acts are essentially communication acts and the communicational universe includes all forms of communication: interpersonal, organizational, group, political, social, intercultural, mediatic, religious, etc.

The communication act affirms its authority over the arts, the writing, the technical inventions, the discourse of modernity in general. To be is to communicate: for the modern man communication is a way of living and of achieving social recognition. The communicative behaviors have as a result, on the one hand an unprecedented openness to novelty and diversity, and on the other hand they can be found at the basis of all deficiencies and problems of institutional and social order.

The relationship between communication and culture is immanent in the history of human communication, deeply interfering with the history of culture itself. "The constitutive dimension of the cultural fact is represented by communication. All cultural actions of man that take place in the process of social activity, are determined by the society, have a purpose and a social function that is achieved through communication." [1].

Communication participates both to the creation of the cultural values and to their transmission.

"The whole universe of culture is a cumulative result of forms of expression and communication that man has invented and experienced throughout history." [2] 
The connection between communication and culture presents at least the following features:

- is bilateral, each component can be found in the composition and the functioning of the other ;

- communication is the main modality of integration of the individual in society and of education ;

- communication is a complex form of social interaction that integrates also a culture seen as a system of codes, specific languages and communication systems;

- communication is social action that contributes to the cohesion of the socialcultural life. [3]

The magnitude of the media phenomenon in the recent years has had a major impact on culture. The unprecedented development of the electronic media is the answer to an acute need of the modern man to inform himself and transmit information forward. Ultimately, the communication media represent endless opportunities in terms of the transmission of knowledge and the diffusion of culture among the population. The media culture in its positive sense has the merit of re-interring, updating, setting and fixing the cultural values, it is intelligible, accessible, and addresses to everyone. Fact that makes us reconsider Mc. Luhan's central thesis stating that, if the history of culture was modified by the evolution of the means of communication, then these means are leading to a subtle transformation of the cultural universe, mentalities and forms of life.

\section{The communication society and its media}

The communication culture has a broader meaning than the media culture, it includes the latter and sums up the cultural products, the media products and those attached to the contemporary culture, including the advertising discourse, signs and symbols as brand name, logo, etc. More importantly, the communication culture promises us instant and free access to information and entertainment. Live broadcasts, social media pages, search engines are accessible at any time, charge-free, facilities that bring in mind an utopic vision of a communication society that appears to be the best possible world.

"It is important to stress upon the fact that, although everything is commodity in today's society, the cyber-space is free, and in consequence, accessible to a plurality of groups and to the political cyber-struggle." [4]

Offering the illusion of an easily accessible, granted happiness for the great mass, the online environment demonstrates its supremacy over any other forms of communication. The new media (websites, social media, blogs, podcasts, videogames, Wikipedias, search engines, etc) have become a significant part of young people's lives, to such an extent that they become their second nature. The confusion that the virtual worlds are equivalent with the real world is one of the greatest dangers in using the online media, knowing the fact that "the young people don't use the media, they live them." [5]

In the virtual reality you can speak unlimitedly, you can be anyone you want to be, do anything you like, explore new worlds, meet the most interesting people or characters. The utopia seems thus complete: the virtual world has all the coordinates of the best possible world: it is a realm of retreat, a wander-wall of the consumer society. According to statistics the number of internet users is growing year by year: 


\begin{tabular}{|c|c|c|c|c|c|c|}
\hline \multicolumn{7}{|c|}{$\begin{array}{l}\text { WORLD INTERNET USAGE AND POPULATION STATISTICS } \\
\text { MARCH 25, } 2017 \text { - Update }\end{array}$} \\
\hline World Regions & $\begin{array}{l}\text { Population } \\
\text { ( } 2017 \text { Est.) }\end{array}$ & $\begin{array}{l}\text { Population } \\
\% \text { of World }\end{array}$ & \begin{tabular}{|c} 
Internet Users \\
31 Mar 2017
\end{tabular} & $\begin{array}{l}\text { Penetration } \\
\text { Rate (\% } \\
\text { Pop.) }\end{array}$ & $\begin{array}{c}\text { Growth } \\
2000- \\
2017\end{array}$ & $\begin{array}{l}\text { Users \% } \\
\text { Table }\end{array}$ \\
\hline Africa & $1,246,504,865$ & $16.6 \%$ & $345,676,501$ & $27.7 \%$ & $7,557.2 \%$ & $9.3 \%$ \\
\hline Asia & $4,148,177,672$ & $55.2 \%$ & $1,873,856,654$ & $45.2 \%$ & $1,539.4 \%$ & $50.2 \%$ \\
\hline Europe & $822,710,362$ & $10.9 \%$ & $636,971,824$ & $77.4 \%$ & $506.1 \%$ & $17.1 \%$ \\
\hline $\begin{array}{ll}\text { Latin America } \\
\text { Caribbean }\end{array}$ & $647,604,645$ & $8.6 \%$ & $385,919,382$ & $59.6 \%$ & $2,035.8 \%$ & $10.3 \%$ \\
\hline Middle East & $250,327,574$ & $3.3 \%$ & $141,931,765$ & $56.7 \%$ & $4,220.9 \%$ & $3.8 \%$ \\
\hline North America & $363,224,006$ & $4.8 \%$ & $320,068,243$ & $88.1 \%$ & $196.1 \%$ & $8.6 \%$ \\
\hline $\begin{array}{l}\text { Oceania } \\
\text { Australia } \\
\end{array}$ & $40,479,846$ & $0.5 \%$ & $27,549,054$ & $68.1 \%$ & $261.5 \%$ & $0.7 \%$ \\
\hline WORLD TOTAL & $7,519,028,970$ & $100.0 \%$ & $3,731,973,423$ & $49.6 \%$ & $933.8 \%$ & $100.0 \%$ \\
\hline
\end{tabular}

People all over the world are using the internet on a daily basis. For many it has become an addiction: the daily existence is almost unbearable in the absence of the online reality that provides unlimited freedom and collective representations that promise a virtual equalization of social chances. In the online there are no rich or poor, there are only users with equal rights, hence the difficult decision: to be or not to be yourself.

Virtual signs, emoticons, abbreviated signs and expressions become the universal language understood by anyone regardless of the country of provenience and of the spoken language. The image is an universal code that can instantly connect people of any nationality.

In this communication society, impregnated by electronic transmission means, the distances between the transmitter and the receiver are practically abolished, as a result, people from the entire planet Earth can participate synchronously at events, they can look at the same work of art, at the same time, listen to the same music, feel emotion by watching the same theater play [6].

\section{The media culture and the crisis of confidence}

The new communication media have the merit of profoundly changing our perception of reality and the way we adjust to it. In addition they create a sense of solidarity and collective participation to culture and public life. The information society champions are convinced that the "new technologies facilitate the access of the majority to the science and the conscience of the world." [7]

The media culture is necessarily a culture of image, a dominant culture that has replaced the traditional forms of culture and requires a new type of literacy in order to decode the new cultural forms. It includes information and entertainment altogether(radio bulletins, albums, cassettes, CD-s, films, talk shows, TV broadcasts, newspapers, websites, blogs, social websites, multimedia.) and implies a profoundly participative activity through which people shape their identities and the surrounding world. There are at least some characteristics of this culture that need to be emphasized:

- the media culture has become the main source of information but also of education and socialization;

- it generates trends, opinions, lifestyle; 
- it has a pronouncedly commercial character;

- is a key to understanding he phenomena of contemporary society, the changes and conflicts of our time.[8]

All groups, even those marginalized, have tried to find their own voice and assert their ideas by offering new perspectives on the world. These voices have contributed together to some of the most innovative social theories and cultural criticism of recent years and to a multi-discourse society.

However, the so-called "communication society" serves the consumer more than the citizen, at the risk of ultimately compromising the future of the written information. It is well known that in the online environment we find, in the electronic format, moreover summaries and texts of no scientific value or that do not correspond to the academic standards and norms. Despite the lack of reliable information, the enthusiasm remains the same, especially among pupils and students who constantly access the virtual space in search of a Grail of electronic information. For this reason, the academic community had to adapt and include the blogs, the educational platforms, and other electronic data bases as an integrated part of the modern educational activity. [9]

The crisis of values can be also one of the effects of the quality of the media message. These messages are free and accessible to anyone, anytime, charge free, but there is no certainty that the message has a value of truth or authenticity. Messages are especially suspicious and marginalized as the critical perspectives launched together with them call them into question or deliberately discredit them. Hence the pessimistic vision and the negative reactions present on the social media, justified by the principles of freedom of expression, of diversity or of the right to difference.

The supremacy of the image in the media discourse, on the other hand, has also negative consequences:
"The takeover of power by the image in information, has had as an end the loss of the informative reasoning."[10]

The result: an acute crisis of confidence. Only 6 percent of people say they have confidence in the press, about the same level of trust that the Americans have in Congress, according to a survey from 2016. The study mirrors past reports that show the public's trust in mass media has reached historic lows last year, according to data gathered by the Media Insight Project, a partnership between The Associated PressNORC Center for Public Affairs Research and the American Press Institute: "Over the last two decades, research shows the public has grown increasingly skeptical of the news industry," the report reads. "The study reaffirms that consumers do value broad concepts of trust like fairness, balance, accuracy, and completeness. At least twothirds of Americans cite each of these four general principles as very important to them."'[11]

According to Eddelman Trust Barometer (2017), the trust in the mass-media institution has decreased with 3 percent, from 2012, with two out of four institutions distrusted.

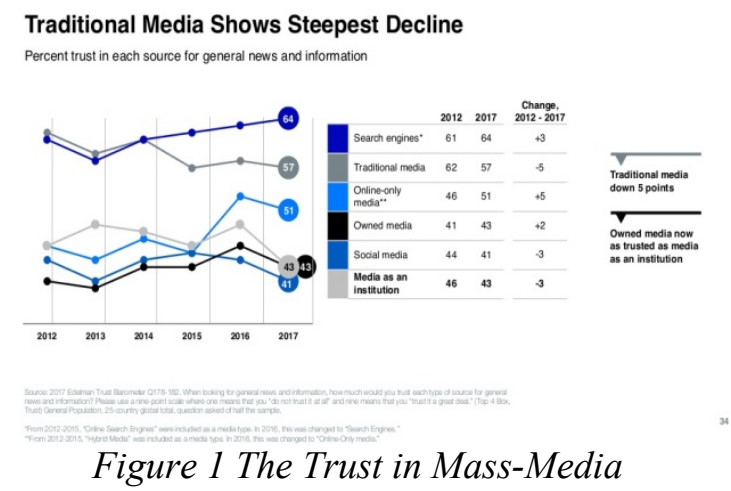

The trust in the traditional media has decreased with 5 percent, reaching $57 \%$, the steepest decline since 2012, followed by the social media (41\%), that has gone down 3 percent . By contrast, the online media has increased by 5 percent, receiving the highest trust rate from its users. [12] 


\section{Conclusions}

Regardless of the criticism, the effect of the new communication media in today's world is spectacular: "a new media culture has emerged, a culture in which images, sounds and shows blend into the fabric of everyday life, dominating the free time, modeling political opinions and social behaviors and offering the substance from which people build their own identity." [11]

Between knowledge, culture and communication there is an indissoluble link: cultural values are established and exist as values as a result of their communicability: communication ensures the continuity of culture and implicitly the social development. The media culture can be regarded as the result of the crisis of the modern society or as a response to an acute need of the people to know, to inform themselves and to express themselves freely. Online environments, especially, provide record and low-cost knowledge for everyone, in addition, they guarantee freedom of expression and collective participation to the political, cultural or social life of the community.

\section{References}

[1] Alexandru Tănase, Cultură şi civilizaţie, Editura Politică, Bucureşti,1977, p. 93

[2] Grigore Georghiu, Filosofia culturii, Cultură şi comunicare, ed a II-a, Editura Comunicare.ro, 2004, p.185

[3] Constantin Stroe, Filosofia comunicării, Editura Universitară, București, 2015, p.130

[4] Ana Bazac, Comunicarea gratuită, o provocare reală, în Adela Rogojinaru, coordonator, Comunicare şi cultură, aplicaţii interdisciplinare, Editura Tritonic, Bucuresti, 2006, p. 23

[5] http.// whatsnewmedia.org/ 2007/07/0/me-myspace-and-i-teens-don't-use-new- media they live-it.

[6] Constantin Stroe, Filosofia comunicării, editura Universitară, Bucuresti, 2015, p 129

[7] Jacques Leprette, Henri Pigeat, Etica şi calitatea informatiei, Editura 1001+1, GRAMAR, Bucuresti, 2006, p. 9

[8] idem, p.23

[9] Dorina Gutu, New Media, editura Tritonic, Bucuresti, 2007, pg 17-69

[10] Douglas Kellner, Cultura media, Editura Institutul European, Iaşi, 2001, p.13

[11] http://www.huffingtonpost.com/entry/trust-in-media_us, TheHuffingtonPost.com, Inc.

[12] http://www.edelman.com/global-results

[13] Douglas Kellner, Op. Cit, p. 29 